\title{
Corrosion on silvered-glass solar reflectors exposed to accelerated aging tests with polluting gases: A microscopic study
}

\author{
A. García-Segura ${ }^{\mathrm{a}, \mathrm{e}}$, A. Fernández-García ${ }^{\mathrm{a}}$, M.J. Ariza ${ }^{\mathrm{b}, 1}$, F. Sutter ${ }^{\mathrm{c}}$, P. Watermeyer ${ }^{\mathrm{d}, \mathrm{f}}, \mathrm{M}$. \\ Schmücker $^{\mathrm{d}}$, L. Valenzuela ${ }^{\mathrm{a}}$ \\ ${ }^{a}$ CIEMAT-PSA, Ctra. Senés, km 4, P.O. Box 22, 04200 Tabernas, Almería, Spain \\ ${ }^{\mathrm{b}}$ Universidad de Almería, Física Aplicada, CITE II-A, 04120, Almería, Spain

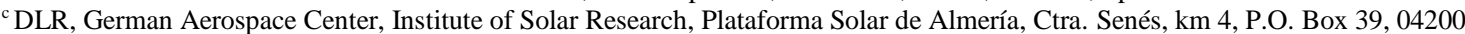 \\ Tabernas, Almería, Spain \\ d) DLR, German Aerospace Center, Institute of Materials Research, Linder Höhe 51147, Köln, Germany
}

\begin{abstract}
Silvered-glass solar reflectors consist of a reflective layer (RL), composed of silver and copper thin-films, back-protected by paint layers on a glass plate. The RL is prone to corrosion, especially in industrial atmospheres with polluting gases. After applying accelerated aging tests with gaseous pollutants $\left(\mathrm{SO}_{2}, \mathrm{H}_{2} \mathrm{~S}, \mathrm{NO}_{2}\right)$, SG-R samples are studied by SEM and EDS, including FIB preparation. As expected the copper thin-film is firstly corroded, followed by the silver corrosion. Deposits of different corrosion products were found on the reflector's surface, depending on the polluting gas used. The rear protective paint layers also play an active role.
\end{abstract}

Keywords: Corrosion of copper and silver thin films; silvered-glass solar reflectors; accelerated aging test; polluting gases; $\mathrm{NO}_{x} ; \mathrm{H}_{2} \mathrm{~S}$; $\mathrm{SO}_{2}$; FIB; SEM; EDS.

\section{Highlights}

- SEM, EDS and FIB are employed to study corrosion in Ag-glass solar reflectors.

- Polluting gases $\left(\mathrm{SO}_{2}, \mathrm{H}_{2} \mathrm{~S}\right.$ and $\left.\mathrm{NO}_{\mathrm{x}}\right)$ have a great influence on reflector degradation.

- For all gas atmospheres, the $\mathrm{Cu}-$ layer is the critical component. It is corroded first and protects silver.

- Corrosion products and mechanisms depend on gas type, humidity and temperature

- Heavy metals of the rear protective paints $(\mathrm{Zn}, \mathrm{Fe})$ also play a significant role.

\footnotetext{
${ }^{1}$ Corresponding author: M.J. Ariza, e-mail: mjariza@ual.es, tel.: +34 950015213.

${ }^{\mathrm{e}}$ Present address: Kurtzio Kalea, 8, 4 A, 48370, Bermeo, Bizkaia, Spain

${ }^{\text {f }}$ Present address: Max-Planck-Institut für Eisenforschung GmbH, Max-Planck-Straße 1, 40237 Düsseldorf, Germany

Author’s e-mail addresses: alexgarsek@gmail.com (A. García-Segura), afernandez@psa.es (A. Fernández-García), mjariza@ual.es (M.J. Ariza), florian.sutter@dlr.de (F. Sutter), p.watermeyer@mpie.de (P. Watermeyer), martin.schmuecker@dlr.de (M. Schmücker), loreto.valenzuela@psa.es (L. Valenzuela).
} 


\section{Introduction}

Solar reflectors used in CSP (concentrating solar power) applications are one of the most sensitive components of concentrating solar thermal facilities in terms of their durability. As identified in our previous works [1-5] and by many other references in the literature [6-17], surrounding atmosphere of the facilities are frequently affected by corrosive gaseous agents $\left(\mathrm{SO}_{2}, \mathrm{H}_{2} \mathrm{~S}\right.$ and $\left.\mathrm{NO}_{2}\right)$ that are likely to degrade the reflector materials, especially their reflective metallic layers, what may be crucial for their optimal performance.

Since the reflective layer of a silvered-glass reflector is usually made of silver and copper, special attention should be paid to the corrosion of these two metallic elements. Schissel and Czanderna (1980) reviewed the interaction between environmental gases and the silver used in polymer-coated reflectors and reported that, after a weak chemisorption of oxygen, polluting gases are able to adsorb on the silver surface in atmospheric conditions [7]. The synergistic effects of atmospheric corrosive gases on metals and alloys during field exposure have already been described [18-20], and the corrosion failure mechanisms during accelerated aging tests of pure silver and copper used in microelectronic devices have also been reviewed [21]. It is long known that the presence of water vapor has a powerful impact on the corrosion of metals, due to the formation of thin aqueous films on their surface $[12,19]$. These water layers act as a medium for the absorption of atmospheric gases and the subsequent corrosion of the metals [1112]. All these processes, i.e. water condensation, pollutant adsorption, solubility of corrosion products and contaminants and corrosion processes, are temperature dependent [12], but to the present time scarce attention has been paid to temperature in the bibliography.

The degradation mechanism of silver surfaces in humidified atmospheres with $\mathrm{SO}_{2}$ as the unique corrosion gas is dependent on the humidity content [22], and in the case of atmospheres containing $\mathrm{H}_{2} \mathrm{~S}$ the corrosion rate of silver is increased by oxygen and humidity [23]. Furthermore, the presence of silver-sulfite compounds on silver surfaces was evidenced for the first time without the help of any additional oxidants, only humidity, aerial oxygen, and $\mathrm{SO}_{2}$ [24]. The corrosion products of silver in environments containing $\mathrm{SO}_{2}$ have been reported to be mainly in the form of sulfites and sulfates [25], while in the case of $\mathrm{H}_{2} \mathrm{~S}$ the main reaction product is silver sulfide $\left(\mathrm{Ag}_{2} \mathrm{~S}\right)$, although more recent works also detected $\mathrm{Ag}_{2} \mathrm{SO}_{4}$ thanks to XPS (X-ray photoelectron spectroscopy) analyses $[17,26]$. Silver sulfidation occurs at very low $\mathrm{H}_{2} \mathrm{~S}$ gas concentrations [9], which makes $\mathrm{H}_{2} \mathrm{~S}$ more aggressive than $\mathrm{SO}_{2}$ [24]. Additionally, $\mathrm{NO}_{2}$ has also been regarded as one of the most harmful gaseous pollutants for silver corrosion [27], which can be adsorbed on the oxygen-covered silver [7]. Some authors asserted that this gas is quite unreactive towards silver in laboratory experiments [11], but it was later stated that $\mathrm{NO}_{2}$ oxidizes silver and also acts as a $\mathrm{pH}$ modifier, since it acidifies the adsorbed water layer on the metallic surface [23]. As a result, the hydroscopic corrosion product $\mathrm{AgNO}_{3}$ is formed, increasing the surface mobility of the adsorbed water layer as well as the tarnish rate. Compared to $\mathrm{H}_{2} \mathrm{~S}$, there is less effect of humidity on the corrosion rate of silver in $\mathrm{NO}_{2}$ environments.

It has been observed that copper exposed to humidified air forms a homogeneous oxide layer which basically consists of a cuprite-like compound $\left(\mathrm{Cu}_{2} \mathrm{O}\right)$ and a water layer adsorbed on it [22]. In aggressive environments, this protective oxide layer changes into a non-protective, multi-component, tarnish layer [28]. Thus, the synergy of humidity and $\mathrm{H}_{2} \mathrm{~S}$ increases the 
copper sulfidation rate $[10,29]$, and $\mathrm{SO}_{2}$ provokes more features on the copper layer, in the form of copper sulfite or copper sulfate hydroxides, such as antlerite [10, 30]. It has been reported that the corrosion products formed by naturally existing $\mathrm{SO}_{2}$ concentrations are normally sulfates [30]. In addition, the presence of $\mathrm{SO}_{2}$ provokes a locally enhanced corrosion attack on the copper surface, in contrast to other exposures such as ozone and $\mathrm{NO}_{2}$, which lead to a uniform corrosion attack [10]. The general conclusion of studies using humid atmospheres with $\mathrm{NO}_{2}$ as the single air pollutant in the ppm range is that this gas has low corrosive effects on copper, being cuprite $\left(\mathrm{Cu}_{2} \mathrm{O}\right)$ and basic copper nitrate the main corrosion products identified by XPS analyses [10, 31-32].

Some authors identified the degradation of silvered-glass reflectors exposed to several types of aggressive atmospheres using reflectance measurements and optical microscopy. Coyle in 1982 [33] tested 22 different glass second-surface mirrors using corrosive vapors (including $\mathrm{H}_{2} \mathrm{~S}$ ) in an environment with high relative humidity, and the most common failure modes were black corrosion spots found at localized sites, probably due to the penetration of moisture and corrosive gases through defects or pores in the paint layers, as also reported in recent studies using Kesternich tests $[3,34]$. Other typical degradation effects of silvered-glass reflectors are silver agglomeration [35-38], copper dissolution [35, 39] and delamination or decohesion at the silver/glass interface [35, 37, 39-40]. However, advanced analysis techniques are required to find out the degradation mechanisms that cause the severe loss of the reflector's optical properties.

In this paper we try to identify the main corrosion mechanisms of silvered-glass reflectors when subjected to single-gas environments in climatic-chamber tests at different temperature, relative humidity and polluting gas type and concentration. Scanning electron microscopy and energy dispersive X-ray microanalysis are used to explore the reflective layer and their protecting coatings after accelerated aging. This way, the degradation of silvered-glass reflectors caused by pollutant gases can be identified and relevant information for the design of more durable reflectors in different polluting atmospheres is provided.

\section{Material and methods}

\subsection{Reflector samples}

The selected silvered-glass reflector is described in our previous publications as silvered-glass Type 1; further details can be found in $[2-3,5]$. The specular reflectance measured according to [UNE 206016, 2018] by a reflectometer at $\lambda=660 \mathrm{~nm}, \theta_{i}=15^{\circ}$, and $\varphi=12.5 \mathrm{mrad}$ is $(0.959 \pm 0.001)$. According to our previous works [41, 41a], its reflective layer is composed by approximately $150 \mathrm{~nm}$ of $\mathrm{Ag}$ and $150 \mathrm{~nm}$ of $\mathrm{Cu}$, protected by three paints layers, a prime coat, intermediate or base coat and finally a top coat, deposited on $4 \mathrm{~mm}$ of low iron glass. Small reflector samples $\left(2 \times 2 \mathrm{~cm}^{2}\right)$ were cut from a commercial parabolic-trough facet to allow the study by advanced techniques in vacuum chambers. All the sample edge are unprotected. Beside this initial damage, a $2 \mathrm{~cm}$-long diagonal scratch was performed on the paints side using a across all the reflective and paint layers as described in [2]. In this way the materials of all the layers are exposed to the aggressive conditions in the aging experiments (see Fig. 1) and they can be easier localized in the microscope. 
Aging experiments are summarized in Table 1. Two types of experiments were performed in three different climatic chambers. On one hand, four single-gas tests were performed in a $\mathrm{VCC}^{3}$ 0034 chamber(Vötsch, Balingen, Germany) with $0 \mathrm{ppm}$ of gas (gas-free experiment) and 25 ppm of $\mathrm{H}_{2} \mathrm{~S}, \mathrm{SO}_{2}$ and $\mathrm{NO}_{2}$, respectively, at $40^{\circ} \mathrm{C}$ constant temperature and $80 \%$ relative humidity for a maximum testing time of 21 days (or cycles). These experiments were based on international standards initially conceived for electronic components and noble metals, such as ISO 10062, IEC 60068-2-42, IEC 60068-2-43 and IEC 60068-2-60 [42]. On the other hand, the rest of tests can be classified as Kesternich tests based on ISO 6988 and DIN 50018 standards with high concentrations of $\mathrm{SO}_{2}$ in water-saturated conditions (acid rain) [43-44]. Three tests without $\mathrm{SO}_{2}$ gas and $100 \% \mathrm{RH}$ at three temperatures $\left(25,40\right.$ and $\left.50{ }^{\circ} \mathrm{C}\right)$ were performed in a condensed water chamber (Vötsch) for 20 days. Finally four tests at different temperatures and gas concentrations were made in a HK 300 M cabinet (Köhler, Lippstadt, Germany) during 20 days or Kerternich cycles. The nomenclature of the test stands for Kesternich test $(\mathrm{K})$, followed by the $\mathrm{SO}_{2}$ concentration $(0.2,1.0$ and $2.0 \mathrm{l})$ and temperature $\left(25,40\right.$ and $\left.50{ }^{\circ} \mathrm{C}\right)$. A sample $\mathrm{K} \_1 \_50$ (Kesternich tested at $1.01 \mathrm{SO}_{2}$ and $50^{\circ} \mathrm{C}$ ) aged only for 10 Kesternich cycles is also used in the FIB study. The effects of all these weathering experiments on the optical properties of the silvered-glass reflector have been already published [2-3], and a summary of the main results is included in this paper at the beginning the corresponding result and discussion subsections.

\subsection{Characterization techniques}

As for the evaluation of the aged reflectors, advanced microscopy and spectroscopy techniques were used. A 3D light microscope model Axio CSM 700, manufactured by Zeiss [45], was used for the optical inspections of defects on the reflective layer of reflectors in the OPAC laboratory at the Plataforma Solar de Almería (PSA, Almería, Spain). After the weathering tests, the glass side of reflector samples were rinsed with running deionized water and dried with a clean tissue at room temperature to perform the optical characterization of the reflective layers across the glass substrate.

Scanning electron microscopy and energy-dispersive X-ray spectroscopy (SEM and EDS) were carried out with a high-vacuum SEM model Ultra 55 manufactured by Zeiss [46], coupled with an EDS unit manufactured by Oxford Instruments, at the Institute of Materials Research, DLR (German Aerospace Center) Cologne, Germany. SEM images in the back-scattered electron (BSE) and secondary electron (SE) modes were recorded at an acceleration voltage of 10-16 kV and 8-11 mm working distance. A small part (aprox. $5 \mathrm{~mm}$ ) of the paints layers at one side of the aged scratch were delaminated using a scalpel. A stereoscopic microscope were used to be sure the paints layers are removed and usually the brilliant original reflective layer is on the sample surface ready to be observed by SEM. In this way the initially protected reflective layer can also be observed and analyzed. After cleaning with dry compressed air, samples were metallized with approximately $10 \mathrm{~nm}$ of Pt to avoid charge effects. The acquisition time for the EDS microanalyses was $60 \mathrm{~s}$, and the dead time was always below 30\%. Analyses were performed at different parts of the samples, including the layers in the area of the scratch that were initially exposed to the corrosive atmosphere, the reflective layer under the paint coatings that was initially not exposed to the testing conditions, and the possible corrosion deposits found on the reflectors surface. 
Furthermore, cross-sections of the reflective and back paint layers of the glass reflector were feasible thanks to a dual-beam focused-ion-beam (FIB) workstation model Helios 600i manufactured by $\mathrm{FEI}^{\mathrm{TM}}$. This equipment was also available at the Institute of Materials Research (DLR, Cologne, Germany) enabling the milling of the sample material around the deposited Pt by sputtering with Ga ions, and the electron and ion imaging of the films crosssections on the micrometer scale [47]. The default parameters used were $30 \mathrm{kV}$ for electron imaging and $0.79 \mathrm{nA}$ for Ga-ion milling.

\section{Results and discussion}

\subsection{Type of polluting gas}

\subsubsection{Gas-free test}

The ' $\mathrm{NG}$ ' sample was aged during 21 days at $40{ }^{\circ} \mathrm{C}$ and $80 \% R H$ without adding any polluting gas. The optical microscopy inspection revealed no remarkable damage, neither on the reflector undamaged area nor on the unprotected edges or scratch. Neither a decrease of specular reflectance was observed [5].

Fig. 2 shows a BSE image of the gas-free sample at the scratch zone. The areas of the scratch that were inspected by EDS are marked with white rectangular shapes. Table 2 lists the main results of the microanalysis at the different areas.

The central dark line in the BSE image corresponds to the glass substrate after scratching the protective paints and reflective layers, since EDS results show the typical composition of a silicate glass (spectrum \#148: $\mathrm{Si} / \mathrm{O}$ ratio of 0.44 and $\mathrm{Na}, \mathrm{Mg}$ and $\mathrm{Ca}$ as the main modifiers cations). The bright lines correspond to the copper and silver rich (spectrum \#147) reflective layers, which is composed of a bottom layer of silver and a top layer of copper according to our previous studies [Ref. TFG]. Since these metallic elements have more atomic weight than the glass elements they back-scatter more electrons and the RL looks very bright in the BSE images. The three paint layers are not clearly distinguished after the scratching and aging test, but two EDS analyses (near the bottom (spectrum \#146) and near the top (spectrum \#145)) were performed in the scratched cross-section of the paint layers. The external surface (not scratched) of the top coat (spectrum \#144) was also analyzed. More detailed microanalyses were also performed on grains of different tonality in the BSE images (see Fig. 3.b and Table 3 as an example). Results show that the paints are very rich in $\mathrm{C}$, $\mathrm{O}$, heavy metals such as $\mathrm{Fe}, \mathrm{Zn}, \mathrm{Ba}$ and traces of $\mathrm{Pb}$, and other light elements such as $\mathrm{Si}, \mathrm{Mg}, \mathrm{Ca}$, and $\mathrm{Ti}$, in agreement with typical protective paints compositions (organic compounds, titanium oxide, iron oxides, zinc oxides, barium sulfate, calcium carbonate and talc) [48]. Titanium is very abundant in the external surface, therefore this chemical element can be used to identify the top coat layer.

Regarding the reflective layer, EDS microanalysis \#147 shows both copper and silver atoms are detected by EDS, since the total copper and silver layer thickness $(\sim 150 \mathrm{~nm}$ each) is below the EDS analyzed thickness $(\sim 1 \mu \mathrm{m})$. The $\mathrm{Ag}$ and $\mathrm{Cu}$ layers initially exposed in the scratch are barely corroded (Fig. 3.a). The metal layers are mainly in its original place (spectrum \#155) and 
a granular structure can be observed at higher magnifications (Fig. 3.c), the brighter grains (spectrum \#160) contain more silver percentage than the darker ones (spectrum \#161). Only small deposits of sulfured corrosion products are found nearby (spectrum \#158). Given that the aging environment did not contain sulfured gases, sulfur atoms must proceed from some contamination of the testing chamber, since sulfates were detected by elemental analysis in the chamber condensation water [49].

\subsection{2. $\mathrm{SO}_{2}$ test}

The ' $\mathrm{SO}_{2}$ ' sample was aged with $25 \mathrm{ppm}$ of $\mathrm{SO}_{2}$ at $40{ }^{\circ} \mathrm{C}$ and $80 \% \mathrm{RH}$ during 21 days. This polluting gas was harmful to the silvered-glass reflector since optical microscopy inspection showed several spots of approximately $150 \mu \mathrm{m}$ on the reflector undamaged area, as well as a maximum penetration of $330 \mu \mathrm{m}$ near the cut edges and an increase of up to $150 \mu \mathrm{m}$ in the scratch width. However, no significant decrease of the specular reflectance was detected [5].

As depicted in Fig. 4, SEM inspection of the $\mathrm{SO}_{2}$ sample shows more corrosion products than the gas-free one, which are clearly observed on the central dark line corresponding to the glass substrate. EDS microanalyses detect sulfur atoms all over the sample surface, including the glass (spectrum \#137) and the external surface of the top coat (spectrum \#133). Abundant sulfur is also detected in the reflective layers, which indicates that the metals are sulfured (spectrum \#136). In addition, high signals of $S$ are found in the paint coatings (spectrum \#134 and \#135), probably due to a reaction of $\mathrm{SO}_{2}$ with the most prevalent metals in paints $(\mathrm{Fe}, \mathrm{Zn}, \ldots)$. Oxygen concentration is very high when the sulfur concentration is high (compare for example EDS quantitative results of the spectra \#135 ( $\mathrm{SO}_{2}$ sample, scratch, bottom) with those of \#146 (NG sample, scratch, bottom), which suggests that the reaction of the original paint components with the $\mathrm{SO}_{2}$ gas produces sulfates or sulfites more than sulfides, in accordance with the bibliography.

Deposits of corrosion products are found all over the sample surface, including the scratch area. Some of these deposits are copper-, zinc- and sulfur-rich (spectrum \#138 and \#140) while others are carbon- and titanium-rich (spectrum \#141, 142 and 143), which indicates that these environmental conditions are very severe not only for the reflective layers but also for the paint protective layers. Therefore, comparing results of the ' $\mathrm{SO}_{2}$ ' to the ' $\mathrm{NG}$ ' samples, we can conclude that the $\mathrm{SO}_{2}$ gas has a great influence on the degradation and removal of the copper layer and some of the main components of the protective paints.

\subsection{3. $\mathrm{H}_{2} \mathrm{~S}$ test}

The ' $\mathrm{H}_{2} \mathrm{~S}$ ' sample was aged with $25 \mathrm{ppm}$ of hydrogen sulfide at $40{ }^{\circ} \mathrm{C}$ and $80 \% \mathrm{RH}$. This reduced sulfur atmosphere was also very harmful to the reflector, as we had already reported $[2,5]$. Optical inspection showed small spots of about $90 \mu \mathrm{m}$ on the reflector undamaged area, but both the maximum penetration from the cut edges $(\sim 270 \mu \mathrm{m})$ and the scratch width increment $(\sim 720 \mu \mathrm{m})$ were higher than for the $\mathrm{SO}_{2}$ sample. Specular reflectance measurements did not detect either this damage level in the sample [5]. 
According to SEM, the area of the scratch looks very different than in the previous samples studied (Fig. 5.a). The dark contrast of the glass phase in the central part of the BSE image is missing and in its stead a symmetric structure of deposits can be observed. $\mathrm{S}$ is found in all the different layers, but it is especially abundant with $\mathrm{Cu}$ and $\mathrm{Ag}$ in the exposed reflective area (spectrum \#110), in some silver-rich deposits (spectrum \#119) and in the inner side of the peeling paints (spectrum \#111), as it is shown in Table 5.

Fig. 5.b shows a detail of the corrosion products deposited on the glass part of the scratch. A series of EDS spectra, from spectrum \#113 to 120, was recorded in areas with different gray levels. Darkest areas correspond to the glass substrate (spectrum \#116), brightest areas are very rich in silver and sulfur (spectrum \#119) and in gray areas a small amount of sulfured silver is found on the glass substrate (spectrum \#114). Consequently, the $\mathrm{H}_{2} \mathrm{~S}$ gas is very corrosive for both copper and silver thin-layers, and the corrosion products remain around the metal original site.

Comparing with the $\mathrm{SO}_{2}$ test, a higher sulfur concentration is found on the reflective layer using $\mathrm{H}_{2} \mathrm{~S}$ as the pollutant $\left(\mathrm{Cu} / \mathrm{S}=0.92\right.$ after $\mathrm{H}_{2} \mathrm{~S}$ and 1.92 after $\mathrm{SO}_{2}$ test $)$, which indicates that $\mathrm{H}_{2} \mathrm{~S}$ is more aggressive towards the silvered-glass reflector. Moreover, the oxygen content is very low in comparison with the $\mathrm{SO}_{2}$ test $\left(\mathrm{O} / \mathrm{S}=0.129\right.$ and 4.18 for $\mathrm{H}_{2} \mathrm{~S}$ and, $\mathrm{SO}_{2}$ respectively), which involves that the corrosion products are mainly sulfides, in agreement with bibliographic data [17].

\subsection{4. $\mathrm{NO}_{2}$ test}

The ' $\mathrm{NO}_{2}$ ' sample was aged at $40{ }^{\circ} \mathrm{C}$ and $80 \% \mathrm{RH}$ with $25 \mathrm{ppm}$ of nitrogen dioxide. Although specular reflectance was as high as in the original reflector, optical microscopy showed again the largest penetration on cut edges (up to $800 \mu \mathrm{m}$ ) and a scratch width increment of approximately $600-700 \mu \mathrm{m}$, comparable to the $\mathrm{H}_{2} \mathrm{~S}$ width increment [5]. However, corrosion spots were not detected by optical inspections in this sample, which suggested that this polluting gas is also harmful but the corrosion mechanisms are different than in the previous aging tests.

Fig. 6 shows some representative BSE micrographs of the scratch area for this sample. Although the glass substrate is clearly observed in the center of the scratch and the reflective layer is found in its original place (between the glass and the paints), SEM images and EDS microanalyses show that the test with $\mathrm{NO}_{2}$ is also harmful for the silvered-glass reflector (see Fig. 6 and Table 6). Although the light nitrogen atoms are hardly detected by EDS, the N K $\alpha$ line clearly appears in all the spectra recorded on the reflective layer (spectra \# 518, and 521 to 523). In addition, corrosion deposits or precipitates are found near the reflective layer (Fig. 6.b to e). In this area, brighter points are $\mathrm{Ag}$ - and $\mathrm{Cu}$-rich, and $\mathrm{N}$ and $\mathrm{O}$ concentrations are also very high, which corroborates the corrosion of the original metals. It should be also noted the high $\mathrm{S}$ concentration detected on the star-shape precipitate showed in Fig. 6.d (spectrum \#522).

The rest of layers contain the elements expected in each of them. According to their quantitative results, the spectrum \#516 was recorded on the top-coat cross-section. Spectrum \#517, recorded at the bottom of the paints cross-section, shows the typical metals of the inner coatings ( $\mathrm{Zn}, \mathrm{Fe}$ and also $\mathrm{Pb}$ ) and a considerable amount of $\mathrm{N}$, which suggests that these heavy metals are also 
oxidized under the $\mathrm{NO}_{2}$ test conditions. However, the top coat looks more stable under these aging conditions since nitrogen was not detected in this layer.

\subsection{Kesternich tests}

\subsubsection{Temperature and humidity effects}

The 'K_0_25', 'K_0_40' and 'K_0_50' samples were aged for 20 days without any polluting gas at $100 \% R H$ and 25,40 and $50{ }^{\circ} \mathrm{C}$, respectively. Significant corrosion was not detected in these three samples either by specular reflectance or by optical microscopy [3].

Fig. and Table 7 show a summary of the main results obtained by SEM and EDS microanalyses of the K_0_40 sample. This sample can be compared with the 'NG' sample aged at the same temperature and $80 \% R H$ (Fig. 2 and Table 2) to determine the effect of water vapor at moderate temperature on the aging of the reflector materials.

For both samples, very similar appearance and composition are obtained in the outer paint surface and in the paint-to-glass cross-section of the aged scratch. However, the exposed reflective layer shows abundant globular deposits (Fig. 7.c), which indicates a higher corrosion degree of the metal layers in the $100 \% R H$ test. These globular deposits are rich in silver, copper and sulfur, despite the absence of sulfured gases in this test. As in the gas-free test, sulfur atoms must proceed from some contamination of the chamber [49].

Comparing the composition of the highly corroded (Fig. 7.c) to the initially protected (Fig. 7.d) areas of the reflective layer, the copper to silver ratio is higher than 2 in the protected noncorroded areas (\#69 and 78 spectra) and lower than 0.7 in both the globular deposits and the highly corroded areas (\#70, 74 and 75 spectra), which entails a faster disappearance of the copper layer in the corroded areas. Moreover, according to \#70 and 75 spectra results, silver must be also sulfured in the globular deposits since the $\mathrm{S}$ to $\mathrm{Cu}$ ratio is higher than that for sulfured-copper compounds (sulfates and sulfides mainly).

In summary, a high humidity at moderate temperature $\left(40{ }^{\circ} \mathrm{C}\right)$ is enough to promote the reflective layer corrosion. The copper thin-layer is corroded first, but environmental conditions are aggressive enough to corrode the exposed silver layer as well. The corrosion products are highly sulfured, which suggests that any $\mathrm{SO}_{2}$ contamination in the atmosphere or sulfate ions in the condensation water can increase the corrosion caused only by humidity, which indicates the aggressiveness of this polluting gas for reflectors durability.

\subsubsection{Effect of $\mathrm{SO}_{2}$ concentration}

The effect of $\mathrm{SO}_{2}$ concentration in Kesternich tests can be studied comparing the K_0.2_40, K_1_40 and K_2_40 samples. The polluting gas concentration is much higher for these tests than for the previous $\mathrm{SO}_{2}$ test $\left(0.21\right.$ corresponds to $667 \mathrm{ppm}$, whereas the $\mathrm{SO}_{2}$ test was performed at $25 \mathrm{ppm}$ ). In these conditions the silvered-glass reflector was clearly damaged after 20 days, increasing the mean total corroded area of the whole reflector surface with the gas concentration and temperature from $2 \%$ to $12 \%$ for K_0.2_40 and K_2_40, respectively [3]. The temperature influence was less significant than the gas concentration, since the K_1_50 sample 
was less damaged than the K_2_40 sample. Corrosion spots, cut edge corrosion penetration and scratch width increment followed the same tendency, and specular reflectance measurement in the scratch area clearly decreased with the gas concentration. Therefore, it is clear that the $\mathrm{SO}_{2}$ gas concentration at high relative humidity is a key factor in the silvered-glass reflector durability. Given that Kesternich conditions are very aggressive, the study of samples aged for less time (10 days) will be also considered.

By SEM studies, the K_0.2_40 sample (Fig. 8.a) is also found to be the least deteriorated sample after 20 Kesternich cycles, but it is still much more damaged than the K_0_40 sample (Fig. 7.a) and the $\mathrm{SO}_{2}$ sample (Fig. 4.a). The reflective layer in the scratch profile has disappeared between the paint layers and the glass substrate, leaving the paints detached from the glass in most of the original edge of the aged scratch (see the upper part of the scratch in Fig. 8.a).

Abundant sulfur and silver corrosion products are found on the paints (Fig. 8.b and spectrum \#6) and also on the glass (not shown). Some bright deposits in the edge of the paint layers (e.g. spectra \#8 and 12 in Fig. 8.b and c respectively) are supposed to be remains of the corroded reflective layer due to their rich content in $\mathrm{Ag}$ and $\mathrm{S}$.

The reflective layer is clearly observed mainly in the delaminated part of the scratch. After the bright areas near the glass edge, the dark areas correspond to some rests of paints (spectrum \#13), probably there due to the cutting tool used for delamination, followed by the bright reflective layer on the bottom of Fig. 8.a.

In contrast to previous samples, silver is not detected in the RL of the K_0.2_40 sample (compare spectra \#8, 12 and 27 in Table 8 with spectra \#69 and 78 in Table 7 and with spectrum \#136 in Table 4). The BSE image of Fig. 8.d was recorded at the end of the delaminated area after moving perpendicular to the scratch ( 2 or $3 \mathrm{~mm}$ from the delaminated scratch edge) and only silver atoms were observed in the RL (spectrum \#27). Copper is not detected either in the inner part of the delaminated paint layers, which suggests that the copper layer has been corroded even far away from the edge of the original scratch.

With some effort, we found some rests of the copper thin-film on the silver layer (Fig. 9) at the end of the delaminated area (near position \#27). Both the silver and the copper are not highly sulfured at those points (spectrum \#28 and \#29 respectively), but the $\mathrm{Cu}$ layer is clearly corroded and the dark spots in the silver layer (Fig. 9.a) can be also a sign of the silver degradation. These findings give rise to the fact that the copper layer is easily corroded by the aggressive agents of the Kesternich test (high $T$, high $\mathrm{RH}$, high $\left[\mathrm{SO}_{2}\right]$ ). After corrosion, the copper ions in the electrolyte must have been carried away from its original place in the reflective layer via a possible way of scape (scratch, fractured edge, diffusion through the paint coatings [39]) and deposited on other parts of the reflector as sulfured copper products, like the ones depicted in Fig. 9. The process of dissolution and migration of $\mathrm{Cu}$ was described in 1980 by Shelby, Vitko and Farrow at localized regions of the metallic film [35] and all of our observations are compatible with this hypothesis.

Moreover, the copper corrosion is progressing with the aging time. In the particular case of K_1_40 sample, the copper layer is found in its original place as a bright line in the BSE image under the paint coatings after 2 and 10 cycles, but it is not visible after 20 cycles, suggesting that in the early stages of the test the whole reflective layer of $\mathrm{Cu}$ and $\mathrm{Ag}$ might not be corroded yet. These findings confirm that the copper layer protects the silver layer from corrosion, but the 
Kesternich conditions easily corrode copper and transport sulfured copper products all over the sample. Finally, without the copper protection, the silver layer is also corroded but remains in its original place, at least in the early stages.

Fig. 8.d also shows a fracture of the three protective paint layers. According to Table 9 EDS results, the top coat (spectrum \#24) is Ti-rich, the abundant $\mathrm{S}, \mathrm{Ba}$ and $\mathrm{Ca}$ detected in the base coat (spectrum \#25) suggest that this layer contains barium sulfate and calcium carbonate, whereas the main component of the prime coat should be talc and iron oxides and zinc (or zinc oxides), since $\mathrm{Fe}, \mathrm{Zn}, \mathrm{Si}$ and $\mathrm{Mg}$ are the most abundant elements in spectrum \#26 quantitative results.

As for the reflective layer, $\mathrm{SO}_{2}$ is also harmful to the paint coatings. We easily found examples of this corrosion in the highly degraded samples, as those shown in Fig. and Table 10 for the K_2_40 sample. In the BSE image, a prime coat trace is observed in lighter color on the glass substrate in a delaminated area near the original scratch (Fig. 10.a). The same lighter color contrast is observed over the non-corroded prime coat when the inner side of the delaminated paint flake is inspected. EDS microanalyses (Table 10) show that the most abundant chemical elements of these deposits are $\mathrm{S}$ and $\mathrm{Zn}$, in contrast with the prime coat composition (spectrum \#93). The prime coat contains zinc that is more easily corroded than copper [50]. These findings involve that the protective coatings are also a critical part of the reflector structure when it is exposed to the aggressive Kesternich environment.

The paint layers are expected to be detached from the reflective layer as a consequence of the corrosion and migration of copper, which will affect the paint/copper interface. The corrosion of some components of the prime coat may also contribute to degradation and easy delamination of the coatings. Notwithstanding, we also found that the silver/glass interface is also affected by the Kesternich conditions, since the reflective layer shows some creases or wrinkles like the ones shown in the secondary electron image recorded in the K_0.2_40 sample (Fig. 11).

\subsubsection{Cross-sectional study by FIB}

In order to further look for the corrosion effects of the Kesternich tests on the reflective layer, a cross-sectional characterization of the reflector samples was pursued. The K_1_50 sample after 10 aging test cycles (K_1_50_10cy) was used in this study. The scratch area of this sample is shown in Fig. 12.a and some quantitative EDS results are listed in Table 11. The reflective layer is not observed between the glass and the paint coatings, as in the K_0.2_40 sample after 20 cycles (Fig. 8), and corrosion deposits or precipitates are abundant in the scratch as well as on top of the cross-section and on the external surface of the paint layers, which was confirmed by EDS microanalysis. After a deliberate delamination of the paint coatings near the scratch edge, the reflective layer (initially under the paints) can be observed on the glass substrate (see the right-bottom side of Fig. 12.a and Fig. 12.b, and spectrum \#58), and also on the inner part of some of the delaminated paint flakes (Fig. 12.c, spectrum \#195 and 196). Although silver atoms were detected in the corrosion products (spectrum \#56), they were not observed in the reflective layer near the scratch (spectra \#58, 195 and 196), which indicates that the silver layer has been completely corroded, at least up to about $1 \mathrm{~mm}$ from the initial scratch edge.

Two FIB analyses were performed on the sites of interest of the K_1_50_10cy sample in the areas shown in Fig. 13. Site 1 was selected near the paint layers at the end of the delaminated 
area, approximately $3 \mathrm{~mm}$ apart from the original scratch edge. In the BSE image (Fig. 13.a bottom) the bright RL shows several lighter islands which are likely to be rests of the original $\mathrm{Cu}$ layer, since copper and silver were detected by EDS in those places. Since the $\mathrm{Cu}$ layer is still there, the reflective layer is expected to be non-corroded under the rest of paints, and therefore Site 1 was selected to study the cross-section of the original reflective layer. Conversely, Site 2 was selected near the scratch edge, where the RL has completely lost the $\mathrm{Cu}$ layer and abundant wrinkles or striae are observed on the remaining part of the RL (Fig. 13.b top), precisely to study the cross-section of a wrinkle (Fig. 13.b bottom).

Some representative BSE micrographs recorded with the FIB workstation during the crosssection preparation are shown in Fig. 14.a and b for Site 1 and 2, respectively. The main steps are the site selection, the electron deposition of a thin Pt layer ( $\left.\mathrm{e}^{-}-\mathrm{Pt}\right)$, the ion deposition of a thicker platinum layer (ion-Pt) to protect the sample layered structure, and finally the milling with Ga-sputtering to obtain the cross-section.

The main results of the Site 1 FIB preparation can be seen in Fig. 15. The top image shows the whole cross-section and the other three images (a-c) show details of three interesting regions at higher magnifications. On the left side of the whole section (Fig. 15.a), the reflective layer can be found on the glass substrate as in its initial state before the corrosion test, i.e. the layered structure of $\mathrm{Ag}$ and $\mathrm{Cu}$ under the paint coatings. Using BSE images, the original thickness of $\mathrm{Cu}$ and $\mathrm{Ag}$ layers are, respectively, $(86 \pm 14) \mathrm{nm}$ and $(77 \pm 13) \mathrm{nm}$. In the middle side (Fig. 15.b), only the silver layer is present and its morphology and thickness have not changed significantly, i.e. it is still a smooth, thin layer $\left((\mathrm{Ag})_{\text {thickness }}=(67 \pm 10) \mathrm{nm}\right)$ that is found in its original place on the glass substrate, which suggests that this part of the silver layer is also non-corroded.

On the right side (Fig. 15.c), the cross-section corresponds to the $\mathrm{Cu}$ island that is shown in the top image of Fig. 14.a. In this region, while $\mathrm{Cu}$ is on the $\mathrm{Ag}$ layer, the prime coat paint has been completely removed by the deliberated delamination. According to its appearance, the silver layer is almost unspoilt $\left((\mathrm{Ag})_{\text {thickness }}=(65 \pm 18) \mathrm{nm}\right)$, but the copper layer looks different if compared to that found under the paints, since it looks darker in the BSE image, its thickness has increased $\left((\mathrm{Cu})_{\text {thickness }}=(123 \pm 16) \mathrm{nm}\right)$ and both interfaces are rougher. Moreover, the electron-deposited $\mathrm{Pt}$ layer $\left(\mathrm{e}^{-}-\mathrm{Pt}\right)$ shows some defects in this region (see $\mathrm{e}^{-}-\mathrm{Pt}$ discontinuities and bubbles on top of the $\mathrm{Cu}$ island region). Given that non-conducting substrates deflect the electrons very strongly and prevent the Pt deposition during the e-beam coating, all these features indicate that the remaining $\mathrm{Cu}$ is highly sulfured or oxidized in this area.

A second cross-section was performed to investigate the silver layer wrinkles near the original scratch (see Fig. 13.b and 14.b). Fig. 16 shows the main results of this second FIB analysis. This cross-section clearly reveals that the silver layer is separated from the glass substrate up to approximately $1 \mu \mathrm{m}$ in the wrinkle center (Fig. 16.a), forming a tunnel over the glass substrate. In addition, the silver layer seems to be corroded because its thickness is not homogeneous and both Pt and glass interfaces are rougher than in its initial state (compare Fig. 16.b and Fig. 15.a Ag layer). Although the silver layer is still continuous, it looks like a beaded necklace (Fig. 16.c). Two unknown layers are observed inside the wrinkle (Fig. 16.a), which could not be discarded as artefacts due to re-depositions of milled material during the FIB milling process.

The reflective layer's wrinkling or tunneling was only observed under the delaminated paints once the $\mathrm{Cu}$ had been completely corroded. Therefore, this phenomenon would occur as a consequence of silver corrosion, probably due to the significant volume increase of the silver 
corrosion products. A tunneling phenomenon at a bigger size scale has been previously reported for silvered-polymer reflectors exposed to high humidity [40].

In summary, this SEM and EDS study has proved that the $\mathrm{SO}_{2}$ gas at high relative humidity is very harmful for the reflective layer of silvered-glass solar reflectors. Firstly, the copper layer is seriously degraded, probably due to the formation of copper sulfates by a corrosion mechanism. The $\mathrm{Cu}$ corrosion products are initially dissolved in the liquid medium and then spread away, to finally appear as corrosion deposits when the humidity level decreases. Once the $\mathrm{Cu}$ layer is removed, the Ag layer is separated from the paint coatings and so its degradation starts. Silver sulfates are probably formed by corrosion, even though the silver layer is more resistant to the aggressive conditions of the Kesternich test. Although some of the corrosion products may also be dissolved in the electrolyte, a substantial part of them shall stay in the layer and provoke an increase of volume in the layer plane, resulting in the observed wrinkles. Finally, this corrosion is responsible for the fragmentation of the layer in small beads that may also be spread away by the liquid phase.

The phenomenology observed agrees with the degradation mechanisms described. Nevertheless, additional chemical analyses are required to corroborate the formation of copper and silver sulfates. Furthermore, subsequent studies are also necessary to investigate the influence on the reflective layer corrosion of the paints layers and the ionic species in the exudation water of the aging tests.

\section{Conclusions}

Scanning electron microscopy and energy dispersive X-ray spectroscopy, combined with focused ion beam cross-section preparation, are useful techniques to study the corrosion mechanism in the layered structure of silvered-glass solar reflectors.

Comparing with the gas-free test, all of the studied polluting gases $\left(\mathrm{SO}_{2}, \mathrm{H}_{2} \mathrm{~S}\right.$ and $\left.\mathrm{NO}_{\mathrm{x}}\right)$ in near environmental conditions $\left(80-100 \% R H, 40{ }^{\circ} \mathrm{C}\right)$ have a great influence on the reflector degradation. As expected, in all cases the copper layer is firstly corroded followed by the silver layer corrosion, but different corrosion products and mechanisms have been found depending on the polluting gas type.

After the $\mathrm{SO}_{2}$ test, corrosion products of $\mathrm{Cu}$ and $\mathrm{S}$, which most likely are copper sulfates, are deposited all over the sample surface. Hence, the copper layer must have suffered from corrosion and dissolution and then been spread away from its original site. In the $\mathrm{H}_{2} \mathrm{~S}$ test, $\mathrm{S}$ is especially present with $\mathrm{Cu}$ and $\mathrm{Ag}$ in the exposed reflective layer. This gas is more aggressive for the silver layer than $\mathrm{SO}_{2}$, and the newly formed corrosion deposits (mainly silver sulfide) remain near the original metal layers. Given the lower amount of corrosion products deposited on the sample surface, $\mathrm{NO}_{2}$ is the less harmful gas. Notwithstanding, both copper and silver layers are also corroded and the corrosion products, which are very rich in $\mathrm{Cu}, \mathrm{Ag}, \mathrm{N}$ and $\mathrm{O}$, remain near the reflective layer.

A high concentration of $\mathrm{SO}_{2}$ at $100 \% \mathrm{RH}$ (Kesternich test) easily corrodes the copper thinlayer. The corrosion products are dissolved and carried away from the reflective layer, resulting in the formation of a gap between the paint layers and the silver layer, which facilitates the corrosion of the latter. Silver is corroded more slowly than copper and its corrosion products 
mainly remain on the layer, provoking a volume increase that separates the silver thin-film from the glass and also wrinkles it on the rigid glass substrate. Moreover, the corrosion of silver progresses quickly at certain points, producing the final fragmentation of the layer in small beads that can be spread away by the condensation liquid phase.

All the corrosive gases studied are not only harmful for the metals of the reflective layer, but also for the components of the protective paints, especially for heavy metal ions of the inner paint layers such as $\mathrm{Zn}$ and $\mathrm{Fe}$, despite being originally oxidized in the initial paints. Our findings indicate that the formulation of the protective paint layers also have an effect on the reflective layer degradation. Therefore, the aging of the whole thin-film reflector structure must be studied to properly understand the reflective layer corrosion mechanisms.

\section{Acknowledgements}

This work has been supported by the Spanish Project SOLTERMIN (Ref. ENE2017-83973-R) of the Ministerio de Economía, Industria y Competitividad (Spanish Ministry of Economy, Industry and Competitiveness). The authors would like to thank Ursula Krebber (Max-PlanckInstitut für Eisenforschung $\mathrm{GmbH}$ ) for performing SEM and EDS measurements. We are also grateful to Lucía Martínez-Arcos (CIEMAT-PSA), Elisa Isabel Ramos (CIEMAT-PSA) and Tomás Jesús Reche-Navarro (DLR-PSA) for their valuable contributions in the exudation-water analysis and aging experiments.

\section{References}

[1] A. García-Segura, A. Fernández-García, M.J. Ariza, F. Sutter, L. Valenzuela, Durability studies of solar reflectors: A review, Renew. Sustain. Energy Rev. 62 (2016) 453-467, http://dx.doi.org/10.1016/j.rser.2016.04.060.

[2] A. García-Segura, A. Fernández-García, M.J. Ariza, F. Sutter, L. Valenzuela, Effects of reduced sulphur atmospheres on reflector materials for concentrating solar thermal applications, Corros. Sci. 133 (2018) 78-93, https://doi.org/10.1016/j.corsci. 2018.01.021.

[3] A. García-Segura, A. Fernández-García, M.J. Ariza, F. Sutter, L. Valenzuela, Degradation of concentrating solar thermal reflectors in acid rain atmospheres, Sol. Energy Mater. Sol. Cells 186 (2018) 92-104, https://doi.org/10.1016/j.solmat.2018.06.032.

[4] A. García-Segura, A. Fernández-García, F. Buendía-Martínez, M.J. Ariza, F. Sutter, L. Valenzuela, Durability Studies of Solar Reflectors Used in Concentrating Solar Thermal Technologies under Corrosive Sulfurous Atmospheres, Sustainability 10 (2018) 3008, https://doi.org/10.3390/su10093008.

[5] A. García-Segura, A. Fernández-García, M.J. Ariza, F. Sutter, T.C. Diamantino, L. MartínezArcos, T.J. Reche-Navarro, L. Valenzuela, Influence of gaseous pollutants and their synergistic effects on the aging of reflector materials for concentrating solar thermal technologies, Sol. Energy Mater. Sol. Cells 200 (2019) 109955, https://doi.org/10.1016/j.solmat. 2019.109955. 
[6] D. Pope, H. R. Gibbens, R.L. Moss, The tarnishing of Ag at naturally-occurring $\mathrm{H}_{2} \mathrm{~S}$ and $\mathrm{SO}_{2}$ levels. Corros. Sci. 8 (1968) 883-887, https://doi.org/10.1016/S0010-938X(68)80141-6.

[7] P. Schissel, A.W. Czanderna, Reactions at the silver/polymer interface: A review, Sol. Energy Mater. 3 (1980) 225-245.

[8] T.E. Graedel, G.W. Kammlott, J.P. Franey, Carbonyl sulfide: Potential agent of atmospheric sulfur corrosion, Science, 212 (1981) 663-665, http://dx.doi.org/10.1126/science. 212.4495.663.

[9] D. W. Rice, P. Peterson, E. B. Rigby, P. B. P. Phipps, R. J. Cappell, R. Tremoureux, Atmospheric corrosion of copper and silver. J. Electrochem. Soc. 128 (1981) 275-284, http://dx.doi.org/10.1149/1.2127403.

[10] T.E. Graedel, J.P. Franey, G.J. Gualtieri, G.W. Kammlott, D.L. Malm, On the mechanism of silver and copper sulfidation by atmospheric $\mathrm{H}_{2} \mathrm{~S}$ and OCS, Corros. Sci., 25 (1985) 1163 1180, https://doi.org/10.1016/0010-938X(85)90060-5

[11] T. E. Graedel, Corrosion mechanisms for silver exposed to the atmosphere, J. Electrochem. Soc. 139 (1992) 1963-1970. https://doi.org/10.1149/1.2221162.

[12] S. Oesch, M. Faller, Environmental effects on materials: The effect of the air pollutants $\mathrm{SO}_{2}, \mathrm{NO}_{2}, \mathrm{NO}$ and $\mathrm{O}_{3}$ on the corrosion of copper, zinc and aluminum. A short literature survey and results of laboratory exposures, Corros. Sci. 39 (1997) 1505-1530, https://doi.org/10.1016/ S0010-938X(97)00047-4.

[13] Watts, S. F. The mass budgets of carbonyl sulfide, dimethyl sulfide, carbon disulfide and hydrogen sulfide. Atmos. Environ. 34, (2000) 761-779, https://doi.org/10.1016/S1352-2310(99) 00342-8.

[14] M. Watanabe, M. Tomita, T. Ichino, Characterization of corrosion products formed on copper in urban, rural/coastal, and hot spring areas, J. Electrochem. Soc. 148 (2001) B522B528, https://doi.org/10.1149/1.1418377.

[15] M. Watanabe, S. Shinozaki, E. Toyoda, K. Asakura, T. Ichino, N. Kuwaki, Y. Higashi, T. Tanaka, Corrosion products formed on silver after a one-month exposure to urban atmospheres, Corrosion 62 (2006) 243-250, https://doi.org/10.5006/ 1.3278270.

[16] R. Lahlou, K. Al Naimi, H. Al Yammahi, J. Wette,F. Sutter, A. Fernández-García, P. R. Armstrong, N. Calvet, T. Shamim, Study and comparison of naturally-aged and As-received silvered-glass reflectors, AIP Conference Proceedings 2033 (2018) 230007, https://doi.org/ 10.1063/1.5067235.

[17] C.E. Sanders, D. Verreault, G.S. Frankel, H.C. Allen, The role of sulfur in the atmospheric corrosion of silver, J. Electrochem. Soc. 162 (2015) C630-C637, http://dx.doi.org/10.1149/ $2.0051512 \mathrm{jes}$.

[18] J.P. Franey, T.E. Graedel, Corrosive effects of mixtures of pollutants, J. Air Pollut. Control Assoc., 35 (1985) 644-648, https://doi.org/10.1080/00022470.1985.10465940.

[19] J.P. Franey, G.W. Kammlott, T.E. Graedel, The corrosion of silver by atmospheric sulfurous gases, Corros.Sci. 25 (1985) 133-143, https://doi.org/10.1016/0010-938X(85)90104-0.

[20] T. Aastrup, M. Wadsak, C. Leygraf, M. Schreiner, In situ studies of the initial atmospheric corrosion of copper influence of humidity, sulfur dioxide, ozone, and nitrogen dioxide, J. Electrochem. Soc. 147 (2000) 2543-2551, https://doi.org/10.1149/ 1.1393566.

[21] J.J. Steppan, J.A. Roth, L.C. Hall, D.A. Jeannotte, S.P. Carbone, A review of corrosion failure mechanisms during accelerated tests, J. Electrochem. Soc. 134 (1987) 175-189, https://doi.org/10.1149/1.2100401.

[22] Ch. Kleber, U. Hilfrich, M. Schreiner, In situ QCM and TM-AFM investigations of the early stages of degradation of silver and copper surfaces, Appl. Surf. Sci. 253 (2007) 37123721, https://doi.org/10.1016/j.apsusc.2006.08.005. 
[23] H. Kim, Corrosion process of silver in environments containing $0.1 \mathrm{ppm} \mathrm{H}_{2} \mathrm{~S}$ and $1.2 \mathrm{ppm}$ $\mathrm{NO}_{2}$, Mater. Corros. 54 (2003) 243-250, https://doi.org/10.1002/maco.200390053.

[24] Ch. Kleber, R. Wiesinger, J. Schnöller, U. Hilfrich, H. Hutter, M. Schreiner, Initial oxidation of silver surfaces by $\mathrm{S}^{2-}$ and $\mathrm{S}^{4+}$ species, Corros. Sci. 50 (2008) 1112-1121, https://doi.org/10.1016/j.corsci.2007.12.001.

[25] L. Yan, K. Xiao, P. Yi, C. Dong, J. Wu, Z. Bai, et al., The corrosion behavior of PCB$\operatorname{ImAg}$ in industry polluted marine atmosphere environment, Mater. Des. 115 (2017) 404-414, https://doi.org/10.1016/j.matdes.2016.11.074.

[26] H. Lin, G.S. Frankel, W.H. Abbott, Analysis of Ag corrosion products, J. Electrochem. Soc. 160 (2013) C345-C355, http://dx.doi.org/10.1149/2.055308jes.

[27] L. Volpe, P.J. Peterson, The atmospheric sulfidation of silver in a tubular corrosion reactor, Corros. Sci. 29 (1989) 1179-1196, https://doi.org/10.1016/0010-938X(89)90065-6.

[28] F. Clarelli, B. De Filippo, R. Natalini, Mathematical model of copper corrosion, Appl. Math. Model. 38 (2014) 4804-4816, https://doi.org/10.1016/j.apm.2014.03.040.

[29] E. D. Mor, A.M. Beccaria, Behaviour of Copper in Artificial Sea Water Containing Sulphides, British Corrosion Journal 10 (1975) 33-38, https://doi.org/10.1179/bcj.1975.10.1.33.

[30] J. Tidblad, T.E. Graedel, Gildes model studies of aqueous chemistry. III. Initial $\mathrm{SO}_{2-}$ induced atmospheric corrosion of copper, Corros. Sci. 38 (1996) 2201-2224, https://doi.org/ 10.1016/S0010-938X(96)00082-0 .

[31] A.R. Mendoza, F. Corvo, Outdoor and indoor atmospheric corrosion of non-ferrous metals, Corros. Sci. 42 (2000) 1123-1147, https://doi.org/10.1016/S0010-938X(99)00135-3.

[32] S. Syed, Atmospheric corrosion of materials, Emirates J. Eng. Res. 11 (2006) 1-24.

[33] R.T. Coyle, J.M. Barrett, P.J. Call, Durability of silver-glass mirrors in moist acid vapors, Sol. Energy Mater. 6 (1982) 351-373, https://doi.org/10.1016/0165-1633(82)90040-5.

[34] A. Fernández-García, R. Díaz-Franco, L. Martínez-Arcos, J. Wette, Study of the effect of acid atmospheres in solar reflectors durability under accelerated aging conditions, Energy Procedia 49 (2014) 1682-1691, https://doi.org/10.1016/j.egypro.2014.03.177.

[35] J.E. Shelby, Jr J. Vitko, R.L. Farrow, Characterization of heliostat corrosion, Sol. Energy Mater. 3 (1980) 185-201, https://doi.org/10.1016/0165-1633(80)90060-X.

[36] Lind, M.A., Chaudiere, D.A., Dake, L.S., Stewart, T.L., Electroless nickel and ion-plated protective coatings for silvered glass mirrors, Tech. Rep. No. PNL-4257 UC-62, Pacific Northwest Laboratory, Battelle (1982).

[37] L. S. Dake, M.A. Lind, The effect of exposing two commercial manufacturers' secondsurface silver/glass mirrors to elevated-temperature, mechanical loading, and high-humidity environments, Tech. Rep. No. PNL-4282 UC-62, Pacific Northwest Laboratory, Battelle, 1982.

[38] Jr J. Vitko, R.E. Benner, J.E. Shelby, Corrosion of thin silver films in an aqueous environment, Sol. Energy Mater. 9 (1983) 51-67, https://doi.org/10.1016/0165-1633(83)900308.

[39] E. Schütz, F. Berger, R. Barillon, P. Audebert, A. Chambaudet, Behaviour of painted mirrors during exposure tests to salt spray, Appl. Surf. Science 120 (1997) 106-118, https://doi.org/10.1016/S0169-4332(97)00219-5.

[40] P. Schissel, G.J. Jorgensen, C. Kennedy, R. Goggin, Silvered-PMMA reflectors, Sol. Energy Mater. Sol. Cells 33 (1994) 183-197, https://doi.org/10.1016/0927-0248(94)90207-0.

[41] F. Sutter, A. Fernández-García, P. Heller, K. Anderson, G. Wilson, M. Schmücker, et al., Durability testing of silvered-glass mirrors, Energy Procedia 69 (2015) 1568-1577, https://doi.org/10.1016/j.egypro.2015.03.110. 
[42] IEC 60068-2-43:2003, Environmental testing - Part 2-43: Tests - Test Kd: Hydrogen sulphide test for contacts and connections, 2003.

[43] ISO 6988:1985, Metallic and other non-organic coatings. Sulfur dioxide test with general condensation of moisture, International Organization for Standardization (ISO), Geneva, 1985.

[44] DIN 50018, Prüfung im kondenswasser-wechselklima mit schwefeldioxidhaltiger atmosphäre (in English: "Testing in a saturated atmosphere in the presence of sulphur dioxide"), Deutsches Institut für Normung, e.V. (DIN), Berlin, 1997.

[45] Carl Zeiss MicroImaging GmbH. Zeiss 3D Light Microscope Model Axio CSM 700 Operating Manual. 2010.

[46] https://www.dlr.de/wf/en/desktopdefault.aspx/tabid-10021/17089_read-41359/ (last accessed $29^{\text {th }}$ Jan 2020)

[47] https://www.dlr.de/wf/en/desktopdefault.aspx/tabid-10034/17115_read-41426/ (last accessed $29^{\text {th }}$ Jan 2020)

[48] R. Girard, C. Delord, A. Disdier, O. Raccurt, Critical constrainsts responsable to solar glass mirror degradation, Energy Procedia 69 (2015) 1519-1528, http://dx.doi.org/ 10.1016/ j.egypro.2015.03.103.

[49] E.I. Ramos, Ion-chromatography internal report, Water analysis laboratory, PSA (Tabernas, Almería, Spain), $10^{\text {th }}$ July 2017.

[50] W.M. Haynes (ed.), CRC Handbook of Chemistry and Physics, 95 ${ }^{\text {th }}$ Ed., CRC Press, New York, 2014. 
$\underline{\text { Tables }}$

Table 1. Sample nomenclature and experimental conditions of the weathering tests.

\begin{tabular}{|c|c|c|c|c|c|c|}
\hline $\begin{array}{c}\text { Name of } \\
\text { sample }\end{array}$ & Gas & {$[G a s](\mathrm{ppm})$} & $T\left({ }^{\circ} \mathbf{C}\right)$ & $\boldsymbol{R H}(\%)$ & $\begin{array}{c}\text { Time } \\
\text { (days) }\end{array}$ & $\begin{array}{l}\text { Climatic } \\
\text { chamber }\end{array}$ \\
\hline NG & --- & 0.0 & 40 & 80 & \multirow{4}{*}{21} & $\begin{array}{c}\mathrm{VCC}^{3} 0034 \\
\text { (Vötsch) }\end{array}$ \\
\hline $\mathrm{SO}_{2}$ & $\mathrm{SO}_{2}$ & 25.0 & 40 & 80 & & \\
\hline $\mathbf{H}_{2} \mathrm{~S}$ & $\mathrm{H}_{2} \mathrm{~S}$ & 25.0 & 40 & 80 & & \\
\hline $\mathrm{NO}_{2}$ & $\mathrm{NO}_{2}$ & 25.0 & 40 & 80 & & \\
\hline K_0_25 & \multirow{3}{*}{--- } & 0.0 & 25 & 100 & \multirow{7}{*}{20} & \\
\hline K_0_40 & & 0.0 & 40 & 100 & & condensed water \\
\hline K_0_50 & & 0.0 & 50 & 100 & & \\
\hline K_0.2_40 & \multirow{4}{*}{$\mathrm{SO}_{2}$} & $666.7(0.21)$ & 40 & 100 & & \multirow{4}{*}{$\begin{array}{l}\text { HK } 300 \text { M } \\
\text { (Köhler) }\end{array}$} \\
\hline K_1_40 & & $3333.3(1.01)$ & 40 & 100 & & \\
\hline K_1_50* & & 3333.3 (1.0 1) & 50 & 100 & & \\
\hline K_2_40 & & 6666.7 (2.0 1) & 40 & 100 & & \\
\hline
\end{tabular}

*K_1_50_10cy sample was aged at the same conditions but only for 10 days

Table 2. Relative atomic percentages calculated from the EDS spectra recorded on the 'NG' sample at the locations marked in Fig. 2. Typical EDS quantification uncertainty $\sim 0.1 \%$.

\begin{tabular}{cccccc}
\hline $\begin{array}{c}\text { Spectrum: } \\
\text { Location: }\end{array}$ & $\begin{array}{c}\text { \# 144 } \\
\text { Paints } \\
\text { (external } \\
\text { surface) }\end{array}$ & $\begin{array}{c}\text { \# 145 } \\
\text { Paints } \\
\text { (scratch, } \\
\text { top) }\end{array}$ & $\begin{array}{c}\text { \# 146 } \\
\text { Paints } \\
\text { (scratch, } \\
\text { bottom) }\end{array}$ & $\begin{array}{c}\text { \# 147 } \\
\text { Reflective } \\
\text { layers }\end{array}$ & $\begin{array}{c}\text { \# 148 } \\
\text { Glass }\end{array}$ \\
\hline $\mathrm{C}$ & 54.99 & 33.37 & 40.50 & 16.93 & ---- \\
$\mathrm{O}$ & 31.84 & 41.95 & 44.05 & 11.07 & 59.74 \\
$\mathrm{Na}$ & ---- & --- & --- & --- & 7.97 \\
$\mathrm{Mg}$ & 0.69 & 3.79 & 1.57 & 0.79 & 2.15 \\
$\mathrm{Al}$ & 0.53 & 0.46 & 0.07 & --- & 0.17 \\
$\mathrm{Si}$ & 1.26 & 3.83 & 1.73 & 13.90 & 26.47 \\
$\mathrm{~S}$ & --- & 0.34 & 1.40 & 0.18 & 0.10 \\
$\mathrm{~K}$ & --- & 0.08 & --- & --- & 0.19 \\
$\mathrm{Ca}$ & --- & 1.11 & 3.95 & 2.01 & 3.11 \\
$\mathrm{Ti}$ & 10.68 & --- & --- & --- & --- \\
$\mathrm{Fe}$ & --- & 5.68 & 2.51 & 0.61 & 0.10 \\
$\mathrm{Cu}$ & --- & --- & --- & 39.52 & --- \\
$\mathrm{Zn}$ & --- & 8.75 & 2.70 & 2.28 & --- \\
$\mathrm{Zr}$ & --- & --- & 0.12 & --- & --- \\
$\mathrm{Ag}$ & --- & --- & --- & 12.72 & --- \\
$\mathrm{Ba}$ & --- & 0.35 & 1.41 & --- & --- \\
$\mathrm{Pb}$ & --- & 0.29 & --- & --- & --- \\
\hline
\end{tabular}


Table 3. Relative atomic percentages calculated from the EDS spectra recorded on the 'NG' sample at higher magnification (Fig. 3) on some interesting points of the paint layers and reflective layers. Typical EDS quantification uncertainty $\sim 0.1 \%$.

\begin{tabular}{ccccccccc}
\hline $\begin{array}{c}\text { Spectrum: } \\
\text { Location: }\end{array}$ & $\begin{array}{c}\text { \# 150 } \\
\text { Paints } \\
\text { (grain) }\end{array}$ & $\begin{array}{c}\text { \# 151 } \\
\text { Paints } \\
\text { (grain) }\end{array}$ & $\begin{array}{c}\text { \# 152 } \\
\text { Paints } \\
\text { (grain) }\end{array}$ & $\begin{array}{c}\text { \# 153 } \\
\text { Paints } \\
\text { (grain) }\end{array}$ & $\begin{array}{c}\text { \# 155 } \\
\text { Metals } \\
\text { (layer) }\end{array}$ & $\begin{array}{c}\text { \# 158 } \\
\text { Metals } \\
\text { (grains) }\end{array}$ & $\begin{array}{c}\text { \#160 } \\
\text { Metal } \\
\text { (bright) }\end{array}$ & $\begin{array}{c}\text { \#161 } \\
\text { Metal } \\
\text { (dark) }\end{array}$ \\
\hline $\mathrm{C}$ & --- & 31.31 & --- & --- & 17.58 & 21.40 & 14.29 & 13.08 \\
$\mathrm{O}$ & 62.22 & 51.99 & 64.19 & 57.79 & 10.54 & 12.48 & 15.77 & 11.95 \\
$\mathrm{Mg}$ & --- & 0.58 & 17.01 & 0.68 & --- & 0.39 & 0.69 & 0.94 \\
$\mathrm{Al}$ & --- & --- & --- & 0.60 & --- & --- & --- & --- \\
$\mathrm{Si}$ & 0.51 & 0.90 & 12.28 & 1.59 & 14.29 & 2.84 & 12.53 & 19.05 \\
$\mathrm{P}$ & --- & --- & --- & 0.24 & --- & --- & --- & --- \\
$\mathrm{S}$ & 16.46 & 0.67 & --- & --- & --- & 20.84 & --- & --- \\
$\mathrm{Ca}$ & 0.94 & 10.75 & 0.16 & 0.21 & 2.10 & 0.57 & 2.16 & 2.75 \\
$\mathrm{Ti}$ & --- & --- & 0.05 & 0.25 & --- & --- & 0.25 & --- \\
$\mathrm{Fe}$ & 0.93 & 1.83 & 2.97 & 36.11 & 0.77 & 0.61 & 0.75 & 0.58 \\
$\mathrm{Cu}$ & --- & --- & --- & --- & 41.72 & 21.34 & 21.59 & 42.62 \\
$\mathrm{Zn}$ & 0.91 & 1.27 & 3.22 & 3.28 & --- & 1.76 & 2.10 & ---- \\
$\mathrm{Sr}$ & 1.07 & --- & --- & --- & --- & --- & --- & --- \\
$\mathrm{Zr}$ & --- & --- & --- & --- & --- & --- & 0.30 & --- \\
$\mathrm{Ag}$ & --- & --- & --- & --- & 13.00 & 17.77 & 29.57 & 9.04 \\
$\mathrm{Ba}$ & 16.96 & 0.60 & --- & 0.13 & --- & --- & --- & --- \\
$\mathrm{Pb}$ & --- & 0.11 & 0.13 & 0.12 & --- & --- & --- & --- \\
\hline
\end{tabular}

Table 4. Relative atomic percentages calculated from the EDS spectra recorded on the $\mathrm{SO}_{2}$ sample at the locations marked in Fig. 4. Typical EDS quantification uncertainty $\sim 0.1 \%$.

\begin{tabular}{|c|c|c|c|c|c|c|c|c|}
\hline Spectr.: & $\# 133$ & $\# 134$ & $\# 135$ & $\# 136$ & $\# 137$ & $\# 138$ & $\# 141$ & $\# 143$ \\
\hline $\begin{array}{c}\text { Loca- } \\
\text { tion: }\end{array}$ & $\begin{array}{c}\text { Paints } \\
\text { (external } \\
\text { surface) }\end{array}$ & $\begin{array}{c}\text { Paints } \\
\text { (scratch, } \\
\text { top) }\end{array}$ & $\begin{array}{c}\text { Paints } \\
\text { (scratch, } \\
\text { bottom) }\end{array}$ & $\begin{array}{c}\text { Reflectiv } \\
\text { e layers }\end{array}$ & Glass & $\begin{array}{c}\text { Deposit } \\
(1)\end{array}$ & $\begin{array}{c}\text { Deposit } \\
(2)\end{array}$ & $\begin{array}{c}\text { Deposit } \\
(3)\end{array}$ \\
\hline $\mathrm{C}$ & 54.38 & 28.08 & --- & 20.94 & --- & --- & 41.79 & 54.71 \\
\hline $\mathrm{O}$ & 31.95 & 51.80 & 66.24 & 28.41 & 58.18 & 61.27 & 40.13 & 30.68 \\
\hline $\mathrm{Na}$ & ---- & 0.82 & --- & 1.04 & 7.55 & --- & 0.97 & 0.38 \\
\hline $\mathrm{Mg}$ & 0.56 & 0.91 & 1.08 & 0.76 & 2.14 & 0.92 & 0.70 & 0.65 \\
\hline $\mathrm{Al}$ & 0.53 & 0.07 & 0.13 & --- & 0.18 & --- & 0.26 & 0.44 \\
\hline $\mathrm{Si}$ & 1.12 & 1.55 & 1.26 & 12.46 & 26.94 & 13.03 & 3.72 & 1.85 \\
\hline $\mathrm{S}$ & 0.15 & 5.56 & 12.10 & 6.79 & 0.47 & 5.94 & 1.68 & 0.13 \\
\hline $\mathrm{K}$ & --- & --- & --- & --- & 0.19 & 0.09 & --- & --- \\
\hline $\mathrm{Ca}$ & & 3.77 & 0.87 & 1.62 & 3.14 & 1.70 & 0.58 & 0.36 \\
\hline $\mathrm{Ti}$ & 11.30 & --- & --- & --- & --- & --- & 3.49 & 8.08 \\
\hline $\mathrm{Fe}$ & --- & 1.95 & 2.58 & 0.35 & --- & 0.19 & 0.85 & 0.63 \\
\hline $\mathrm{Cu}$ & --- & --- & 0.29 & 13.01 & 0.61 & 9.99 & 2.41 & 0.20 \\
\hline $\mathrm{Zn}$ & --- & 4.26 & 15.28 & 2.68 & 0.60 & 6.77 & 1.95 & 0.56 \\
\hline $\mathrm{Ag}$ & --- & --- & --- & 11.94 & --- & 0.09 & 1.51 & 1.33 \\
\hline $\mathrm{Ba}$ & --- & 1.21 & 0.16 & --- & --- & --- & --- & --- \\
\hline
\end{tabular}


Table 5. Relative atomic percentages calculated from the EDS spectra recorded on the $\mathrm{H}_{2} \mathrm{~S}$ sample at the locations marked in Fig. 5.a. Typical EDS quantification uncertainty $\sim 0.1 \%$.

\begin{tabular}{|c|c|c|c|c|c|c|c|c|}
\hline Spectr.: & $\# 108$ & $\# 109$ & $\# 110$ & \#114 & $\# 116$ & $\# 119$ & \#111 & $\# 112$ \\
\hline $\begin{array}{l}\text { Loca- } \\
\text { tion: }\end{array}$ & $\begin{array}{c}\text { Paints } \\
\text { (scratch, } \\
\text { top) }\end{array}$ & $\begin{array}{l}\text { Paints } \\
\text { (scratch, } \\
\text { bottom) }\end{array}$ & $\begin{array}{l}\text { Reflecti- } \\
\text { ve layers }\end{array}$ & $\begin{array}{c}\text { Deposit } \\
\text { (gray) }\end{array}$ & $\begin{array}{l}\text { Deposit } \\
\text { (dark) }\end{array}$ & $\begin{array}{l}\text { Deposit } \\
\text { (bright) }\end{array}$ & $\begin{array}{c}\text { Peeling } \\
\text { paint } \\
\text { (bright) } \\
\end{array}$ & $\begin{array}{c}\text { Peeling } \\
\text { paint } \\
\text { (dark) } \\
\end{array}$ \\
\hline C & 32.89 & 31.38 & 13.00 & --- & --- & 9.19 & 31.95 & 30.05 \\
\hline 0 & 28.91 & 32.05 & 3.79 & 40.97 & 55.70 & 9.89 & 25.93 & 38.84 \\
\hline $\mathrm{Na}$ & 0.84 & --- & --- & 7.51 & 3.70 & 1.37 & 0.85 & 1.81 \\
\hline $\mathrm{Mg}$ & 2.03 & 4.18 & 0.55 & 2.45 & 2.02 & --- & 2.21 & 5.47 \\
\hline Al & 0.20 & 0.52 & --- & 0.24 & 0.18 & --- & 0.41 & 0.42 \\
\hline Si & 3.11 & 5.06 & 10.27 & 36.18 & 32.52 & 8.63 & 3.08 & 4.97 \\
\hline$S$ & 4.45 & 2.48 & 29.39 & 3.71 & 0.57 & 14.73 & 10.94 & 1.04 \\
\hline $\mathrm{Cl}$ & --- & 0.14 & --- & --- & --- & --- & --- & --- \\
\hline K & --- & 0.24 & --- & 0.30 & 0.23 & --- & --- & 0.10 \\
\hline $\mathrm{Ca}$ & 10.19 & 0.87 & 1.49 & 4.62 & 3.35 & --- & 0.34 & 0.37 \\
\hline $\mathrm{Ti}$ & --- & --- & --- & --- & --- & --- & --- & --- \\
\hline $\mathrm{Fe}$ & 9.02 & 12.33 & 0.28 & --- & --- & --- & 4.11 & 7.56 \\
\hline $\mathrm{Cu}$ & 0.43 & --- & 27.09 & 0.41 & --- & --- & 10.58 & --- \\
\hline $\mathrm{Zn}$ & 3.36 & 10.12 & 1.05 & --- & --- & --- & 5.93 & 9.08 \\
\hline $\mathrm{Ag}$ & 0.55 & 0.12 & 13.11 & 3.61 & 1.71 & 56.19 & 3.68 & --- \\
\hline $\mathrm{Ba}$ & 4.00 & 0.10 & --- & --- & --- & --- & --- & --- \\
\hline $\mathrm{Pb}$ & --- & 0.41 & --- & --- & --- & --- & --- & 0.29 \\
\hline
\end{tabular}

Table 6. Relative atomic percentages calculated from the EDS spectra recorded on the ' $\mathrm{NO}_{2}$ ' sample at the locations marked in Fig. 6. Typical EDS quantification uncertainty $\sim 0.1 \%$.

\begin{tabular}{|c|c|c|c|c|c|c|c|c|}
\hline $\begin{array}{l}\text { Spectr.: } \\
\text { Locat.: }\end{array}$ & $\begin{array}{c}\text { \# } \mathbf{5 1 5} \\
\text { Paints } \\
\text { (external } \\
\text { surface) }\end{array}$ & $\begin{array}{c}\text { \# } 516 \\
\text { Paints } \\
\text { (scratch, } \\
\text { top) }\end{array}$ & $\begin{array}{c}\text { \# } 517 \\
\text { Paints } \\
\text { (scratch, } \\
\text { bottom) }\end{array}$ & $\begin{array}{c}\text { \# } \mathbf{5 1 8} \\
\text { Reflec- } \\
\text { tive } \\
\text { layers }\end{array}$ & $\begin{array}{l}\text { \# } 519 \\
\text { Glass }\end{array}$ & $\begin{array}{c}\mathbf{5 2 1} \\
\mathrm{RL} \\
\text { (brigh } \\
\text { t dots) }\end{array}$ & $\begin{array}{c}\text { \# } 522 \\
\text { RL (star- } \\
\text { shaped } \\
\text { deposit) }\end{array}$ & $\begin{array}{c}\text { \# } \mathbf{5 2 3} \\
\mathrm{RL} \\
\text { (texturized } \\
\text { surface) }\end{array}$ \\
\hline$C$ & 65.87 & 30.88 & 24.13 & 9.13 & 6.30 & 28.53 & 38.86 & 29.71 \\
\hline$N$ & --- & --- & 14.15 & 23.47 & 7.56 & 4.56 & 4.43 & 2.64 \\
\hline 0 & 28.97 & 48.09 & 48.66 & 28.07 & 66.19 & 50.22 & 31.02 & 50.06 \\
\hline $\mathrm{Na}$ & --- & --- & --- & --- & 3.65 & --- & --- & --- \\
\hline $\mathrm{Mg}$ & & 6.58 & 1.46 & --- & 0.82 & 0.79 & 0.73 & 0.60 \\
\hline $\mathrm{Al}$ & 0.38 & --- & --- & --- & --- & 0.13 & 0.06 & 0.12 \\
\hline $\mathrm{Si}$ & --- & 11.04 & 1.02 & 3.55 & 13.96 & 4.23 & 3.30 & 2.39 \\
\hline S & --- & --- & --- & --- & --- & 0.50 & 8.03 & --- \\
\hline $\mathrm{Cl}$ & & & & & & 2.62 & --- & 2.37 \\
\hline $\mathrm{Ca}$ & --- & --- & 3.21 & --- & 1.53 & 2.09 & 0.67 & 0.84 \\
\hline $\mathrm{Ti}$ & 4.78 & 3.41 & --- & --- & --- & 0.86 & 0.98 & 0.96 \\
\hline $\mathrm{Fe}$ & --- & --- & 3.71 & --- & --- & 0.43 & 0.65 & 0.42 \\
\hline $\mathrm{Cu}$ & --- & --- & --- & 22.98 & --- & 2.17 & 8.56 & 4.99 \\
\hline $\mathrm{Zn}$ & --- & --- & 2.01 & --- & --- & --- & 5.19 & 1.23 \\
\hline $\mathrm{Ag}$ & --- & --- & --- & 12.80 & --- & 2.87 & 2.70 & 2.31 \\
\hline $\mathrm{Ba}$ & --- & --- & --- & --- & --- & --- & --- & --- \\
\hline $\mathrm{Pb}$ & --- & --- & 1.65 & --- & --- & --- & --- & 1.36 \\
\hline
\end{tabular}


Table 7. Relative atomic percentages calculated from the EDS spectra recorded on the K_0_40 sample at the locations marked in Fig. 7. Typical EDS quantification uncertainty $\sim 0.1 \%$.

\begin{tabular}{ccccccccc}
\hline $\begin{array}{c}\text { Spectr.: } \\
\text { Locat.: }\end{array}$ & $\begin{array}{c}\text { \# 64 } \\
\text { Paints } \\
\text { (external } \\
\text { surface) }\end{array}$ & $\begin{array}{c}\text { \# } 65 \\
\text { Paints } \\
\text { (scratch) }\end{array}$ & $\begin{array}{c}\text { \# 67 } \\
\text { Glass } \\
\text { (scratch) }\end{array}$ & $\begin{array}{c}\text { \# 69 } \\
\text { Reflective } \\
\text { layer (RL) }\end{array}$ & $\begin{array}{c}\text { \# 70 } \\
\text { Deposits } \\
\text { (bright) }\end{array}$ & $\begin{array}{c}\text { \# 74 } \\
\text { RL } \\
\text { (corroded) }\end{array}$ & $\begin{array}{c}\text { \# 75 } \\
\text { RL } \\
\text { (deposit) }\end{array}$ & $\begin{array}{c}\text { \#78 } \\
\text { RL } \\
\text { (protect- } \\
\text { ted) }\end{array}$ \\
\hline $\mathrm{C}$ & 54.78 & 37.38 & --- & 24.23 & 14.65 & 22.81 & 19.24 & 17.95 \\
$\mathrm{O}$ & 32.75 & 35.34 & 59.31 & 18.26 & 12.20 & 21.49 & 27.03 & 8.09 \\
$\mathrm{Na}$ & --- & --- & 8.15 & --- & --- & 2.74 & --- & --- \\
$\mathrm{Mg}$ & 0.57 & 3.76 & 2.21 & 0.93 & --- & 1.51 & 0.61 & --- \\
$\mathrm{Al}$ & 0.44 & 0.60 & --- & --- & --- & --- & --- & --- \\
$\mathrm{Si}$ & 1.11 & 4.39 & 26.97 & 12.53 & 3.95 & 22.69 & 2.51 & 14.56 \\
$\mathrm{~S}$ & --- & 0.21 & --- & 0.52 & 23.17 & 0.62 & 10.88 & --- \\
$\mathrm{Cl}$ & --- & 0.11 & --- & 0.23 & --- & 0.28 & --- & --- \\
$\mathrm{K}$ & --- & 0.21 & 0.17 & --- & --- & --- & --- & --- \\
$\mathrm{Ca}$ & --- & 0.73 & 3.20 & 1.62 & 0.89 & 2.92 & --- & 2.18 \\
$\mathrm{Ti}$ & 10.24 & 0.22 & --- & --- & --- & --- & --- & \\
$\mathrm{Fe}$ & --- & 8.09 & --- & 0.84 & 0.65 & 0.26 & 1.04 & 0.34 \\
$\mathrm{Cu}$ & --- & 0.22 & --- & 27.51 & 17.95 & 7.88 & 2.57 & 44.33 \\
$\mathrm{Zn}$ & --- & 8.16 & --- & 1.57 & 1.00 & 0.82 & 0.89 & --- \\
$\mathrm{Zr}$ & 0.10 & 0.17 & --- & 0.19 & 0.32 & --- & --- & -- \\
$\mathrm{Ag}$ & --- & --- & --- & 11.56 & 25.21 & 15.97 & 35.23 & 12.57 \\
$\mathrm{Ba}$ & --- & 0.16 & --- & --- & --- & --- & -- & --- \\
$\mathrm{Pb}$ & --- & 0.25 & --- & --- & --- & --- & --- & --- \\
\hline
\end{tabular}

Table 8. Relative atomic percentages from EDS spectra recorded on the K_0.2_40 sample at the locations marked in Fig. 8 and 9. Typical EDS quantification uncertainty $\sim 0.1 \%$.

\begin{tabular}{|c|c|c|c|c|c|c|c|c|}
\hline \multirow[b]{2}{*}{$\begin{array}{c}\text { Spectr.: } \\
\text { Locat.: }\end{array}$} & \multicolumn{3}{|c|}{ Original edge } & \multicolumn{5}{|c|}{ Delaminated edge } \\
\hline & $\begin{array}{c}\text { \# } 2 \\
\text { Paints } \\
\text { (external } \\
\text { surface) }\end{array}$ & $\begin{array}{c}\mathbf{6} \\
\text { Deposit } \\
\text { on paints } \\
\text { (scratch) }\end{array}$ & $\begin{array}{c}\text { \# } 8 \\
\text { RL near } \\
\text { the glass } \\
\text { (corroded) }\end{array}$ & $\begin{array}{c}\begin{array}{c}12 \\
\text { RL near }\end{array} \\
\text { the glass } \\
\text { (corroded) }\end{array}$ & $\begin{array}{c}\text { \# } 15 \\
\text { RL near } \\
\text { scratch } \\
\text { edge }\end{array}$ & $\begin{array}{c}\text { \#27 } \\
\text { RL far } \\
\text { from the } \\
\text { edge }\end{array}$ & $\begin{array}{c}\text { \#28 } \\
\text { RL far: } \\
\text { Ag layer } \\
\text { (uncorr.) }\end{array}$ & $\begin{array}{c}\text { \#29 } \\
\text { RL far: } \\
\text { Cu layer } \\
\text { traces }\end{array}$ \\
\hline $\mathrm{C}$ & 54.55 & 20.89 & --- & 11.10 & --- & --- & 11.16 & --- \\
\hline 0 & 30.05 & 15.03 & 61.05 & 12.68 & 38.62 & 20.81 & 23.44 & 35.37 \\
\hline $\mathrm{Na}$ & --- & --- & 3.95 & 2.33 & 7.73 & 7.10 & 5.97 & 2.67 \\
\hline $\mathrm{Mg}$ & 0.67 & --- & 2.30 & 1.04 & 2.48 & 2.72 & 2.26 & 1.51 \\
\hline $\mathrm{Al}$ & 0.22 & --- & 0.40 & --- & --- & --- & 0.68 & --- \\
\hline $\mathrm{Si}$ & 1.23 & 1.41 & 10.66 & 17.20 & 36.06 & 41.23 & 33.91 & 25.53 \\
\hline $\mathbf{S}$ & 0.31 & 26.99 & 4.79 & 17.18 & 1.02 & 0.24 & --- & --- \\
\hline $\mathrm{Cl}$ & --- & 0.34 & --- & --- & --- & 0.26 & --- & --- \\
\hline $\mathrm{K}$ & --- & --- & --- & --- & --- & 0.32 & --- & --- \\
\hline $\mathrm{Ca}$ & --- & 0.12 & 0.73 & 2.02 & 4.47 & 5.46 & 4.27 & 3.16 \\
\hline $\mathrm{Ti}$ & 12.80 & & --- & --- & --- & --- & & --- \\
\hline $\mathrm{Fe}$ & --- & 2.27 & 6.42 & 0.47 & --- & --- & 0.24 & --- \\
\hline $\mathrm{Cu}$ & --- & 28.83 & 0.67 & 1.49 & 0.54 & --- & --- & 16.68 \\
\hline $\mathrm{Zn}$ & --- & 2.19 & --- & --- & --- & --- & --- & -- \\
\hline $\mathrm{Zr}$ & 0.17 & --- & 0.20 & --- & 0.20 & --- & --- & --- \\
\hline $\mathrm{Ag}$ & --- & 0.76 & 8.82 & 34.50 & 8.89 & 21.86 & 18.07 & 15.09 \\
\hline $\mathrm{Ba}$ & --- & 1.17 & --- & --- & --- & --- & --- & --- \\
\hline
\end{tabular}


Table 9. Relative atomic percentages from EDS spectra recorded on the delaminated area of K_0.2_40 sample at the locations marked in Fig. 8c and d. Typical uncertainty $\sim 0.1 \%$.

\begin{tabular}{cccccc}
\hline $\begin{array}{c}\text { Spectrum: } \\
\text { Location: }\end{array}$ & $\begin{array}{c}\text { \# 13 } \\
\text { RL and paints } \\
\text { (bright) }\end{array}$ & $\begin{array}{c}\text { \# 14 } \\
\text { RL and paints } \\
\text { (dark) }\end{array}$ & $\begin{array}{c}\text { \# 24 } \\
\text { Paint layers } \\
\text { (top coat) }\end{array}$ & $\begin{array}{c}\text { \# 25 } \\
\text { Paint layers } \\
\text { (base coat) }\end{array}$ & $\begin{array}{c}\text { \# 26 } \\
\text { Paint layers } \\
\text { (prime coat) }\end{array}$ \\
\hline $\mathrm{C}$ & --- & 41.59 & 46.70 & 38.25 & --- \\
$\mathrm{O}$ & 53.74 & 23.96 & 35.78 & 38.26 & 48.40 \\
$\mathrm{Na}$ & --- & 2.00 & --- & --- & 4.22 \\
$\mathrm{Mg}$ & 7.77 & 1.55 & 1.31 & 2.44 & 8.56 \\
$\mathrm{Al}$ & 1.73 & 0.25 & 0.57 & & 0.70 \\
$\mathrm{Si}$ & 11.93 & 12.86 & 2.09 & 2.30 & 8.13 \\
$\mathrm{~S}$ & 1.83 & 3.94 & 0.38 & 2.26 & --- \\
$\mathrm{K}$ & 0.27 & --- & --- & --- & 0.24 \\
$\mathrm{Ca}$ & 0.17 & 1.40 & 0.06 & 6.60 & 0.79 \\
$\mathrm{Ti}$ & --- & --- & 12.96 & & --- \\
$\mathrm{Fe}$ & 20.95 & 4.74 & --- & 4.39 & 15.13 \\
$\mathrm{Cu}$ & --- & 0.57 & --- & & --- \\
$\mathrm{Zn}$ & 0.58 & --- & --- & 2.47 & 12.94 \\
$\mathrm{Zr}$ & 0.18 & 0.15 & 0.14 & 0.14 & 0.28 \\
$\mathrm{Ag}$ & 0.25 & 7.00 & --- & --- & 0.14 \\
$\mathrm{Ba}$ & 0.14 & --- & --- & 2.74 & --- \\
$\mathrm{Pb}$ & 0.45 & --- & --- & 0.17 & 0.47 \\
\hline
\end{tabular}

Table 10. Relative atomic percentages from EDS spectra recorded on the delaminated area and the paint flake of K_2_40 sample showing light gray deposits at the locations marked in Fig. 10.a and b respectively. Typical EDS quantification uncertainty $\sim 0.1 \%$.

\begin{tabular}{|c|c|c|c|c|c|c|}
\hline $\begin{array}{l}\text { Spectrum: } \\
\text { Location: }\end{array}$ & $\begin{array}{c}\mathbf{8 8} \\
\text { Deposit on } \\
\text { glass (1) } \\
\end{array}$ & $\begin{array}{c}\mathbf{8 9} \\
\text { Deposit on } \\
\text { glass (2) } \\
\end{array}$ & $\begin{array}{c}\mathbf{9 0} \\
\text { Deposit on } \\
\text { glass (3) } \\
\end{array}$ & $\begin{array}{c}\# 93 \\
\text { Paint flake } \\
\text { (prime coat) } \\
\end{array}$ & $\begin{array}{c}\text { \# } 94 \\
\text { Deposit on } \\
\text { paint flake (1) }\end{array}$ & $\begin{array}{c}\text { \# } 95 \\
\text { Deposit on } \\
\text { paint flake (2) }\end{array}$ \\
\hline$C$ & --- & --- & --- & 50.02 & 5.34 & 10.02 \\
\hline 0 & 68.31 & 55.01 & 61.04 & 32.21 & 63.54 & 59.57 \\
\hline $\mathrm{Na}$ & 2.47 & 2.92 & 6.24 & --- & 2.39 & 2.30 \\
\hline $\mathrm{Mg}$ & 1.60 & 2.15 & 2.14 & 1.80 & 1.52 & 1.55 \\
\hline $\mathrm{Al}$ & --- & --- & 0.17 & 0.64 & --- & 0.13 \\
\hline $\mathrm{Si}$ & 1.26 & 0.51 & 21.25 & 4.08 & 0.07 & 1.21 \\
\hline$S$ & 13.40 & 21.52 & 2.40 & 1.99 & 13.95 & 10.57 \\
\hline K & --- & --- & 0.12 & 0.14 & --- & --- \\
\hline $\mathrm{Ca}$ & 0.19 & 0.28 & 2.22 & --- & --- & --- \\
\hline $\mathrm{Fe}$ & 0.34 & 1.38 & 0.13 & 8.31 & 1.19 & 3.96 \\
\hline $\mathrm{Zn}$ & 12.37 & 15.87 & 4.20 & 0.33 & 11.90 & 10.13 \\
\hline $\mathrm{Zr}$ & 0.06 & 0.37 & 0.09 & 0.09 & 0.10 & 0.14 \\
\hline $\mathrm{Ag}$ & --- & --- & --- & 0.05 & --- & 0.26 \\
\hline $\mathrm{Pb}$ & --- & --- & --- & 0.34 & --- & 0.17 \\
\hline
\end{tabular}


Table 11. Relative atomic percentages from EDS spectra recorded on the ' $\mathrm{K}$ 1_50' sample after 10 Kesternich cycles at the locations marked in Fig. 12. Typical uncertainty $\sim 0.1 \%$.

\begin{tabular}{|c|c|c|c|c|c|c|c|c|}
\hline $\begin{array}{l}\text { Spectr.: } \\
\text { Locat.: }\end{array}$ & $\begin{array}{c}\text { \# } \mathbf{5 4} \\
\text { Paints } \\
\text { (external } \\
\text { surface) }\end{array}$ & $\begin{array}{c}\text { \# } 55 \\
\text { Paints } \\
\text { (scratch) }\end{array}$ & $\begin{array}{c}\text { \# } 56 \\
\text { Glass } \\
\text { (deposit) }\end{array}$ & $\begin{array}{c}\mathbf{5 7} \\
\text { Glass } \\
\text { (clean) }\end{array}$ & $\begin{array}{c}\text { \# } 58 \\
\text { RL } \\
\text { (on glass, } \\
\text { protected) }\end{array}$ & $\begin{array}{c}\text { \# } 193 \\
\text { Paints } \\
\text { (prime } \\
\text { coat/RL) }\end{array}$ & $\begin{array}{c}\text { \# } 195 \\
\text { RL (bright } \\
\text { on paint } \\
\text { flake) }\end{array}$ & $\begin{array}{c}\# 196 \\
\mathrm{RL} \text { (darker } \\
\text { on paint } \\
\text { flake) }\end{array}$ \\
\hline C & 50.92 & 38.26 & 16.13 & --- & --- & 49.49 & 22.05 & 49.29 \\
\hline 0 & 35.75 & 45.37 & 15.48 & 60.29 & 28.78 & 36.04 & 11.01 & 12.11 \\
\hline $\mathrm{Na}$ & --- & --- & 2.14 & 7.93 & 6.83 & --- & --- & --- \\
\hline $\mathrm{Mg}$ & 3.45 & 2.87 & 0.84 & 2.22 & 2.09 & 1.94 & 0.84 & 1.69 \\
\hline Al & --- & 0.53 & --- & --- & --- & 0.61 & 0.90 & 0.91 \\
\hline $\mathrm{Si}$ & 4.37 & 4.82 & 16.39 & 26.20 & 37.29 & 3.78 & 3.26 & 4.87 \\
\hline S & 0.34 & 1.54 & 18.80 & --- & 1.27 & 0.80 & 2.02 & 1.65 \\
\hline $\mathrm{Cl}$ & --- & --- & --- & --- & --- & --- & 0.35 & --- \\
\hline K & --- & 0.14 & --- & 0.17 & --- & 0.14 & --- & --- \\
\hline $\mathrm{Ca}$ & --- & --- & 2.50 & 3.19 & 5.07 & --- & --- & --- \\
\hline $\mathrm{Ti}$ & 5.16 & --- & --- & --- & -- & --- & --- & --- \\
\hline $\mathrm{Fe}$ & --- & 5.01 & --- & --- & --- & 6.63 & 10.95 & 12.05 \\
\hline $\mathrm{Cu}$ & --- & --- & 23.46 & --- & --- & --- & --- & --- \\
\hline $\mathrm{Zn}$ & --- & 0.68 & 1.03 & --- & --- & 0.14 & 0.17 & 0.22 \\
\hline $\mathrm{Ag}$ & --- & 0.77 & 3.24 & --- & 18.67 & 0.07 & 47.67 & 16.53 \\
\hline $\mathrm{Pb}$ & --- & --- & --- & --- & --- & 0.37 & 0.77 & 0.69 \\
\hline
\end{tabular}




\section{Figure Captions}

Fig. 1. Back-side view of a $2 \times 2 \mathrm{~cm}^{2}$ sample of the original silvered-glass reflector with the diagonal scratch (a) and schematic representation of the reflector layered structure near the scratch (b).

Fig. 2. BSE micrograph of the scratch of the silvered-glass reflector after 21 days of the gas-free test.

Fig. 3. BSE micrographs showing the scratched reflective layers of the ' $\mathrm{NG}$ ' sample at $\times 5.0 \mathrm{k}$ magnification (a), details of the paints structure at $\times 5.0 \mathrm{k}$ (b) and the reflective layers at $\times 30.0 \mathrm{k}$ (c), pointing out the EDS spectra listed in Table 3. EDS spectrum of the non-corroded metallic layer (d) and corrosion deposits (e).

Fig. 4. BSE micrograph at $\times 200$ (a) and $\times 5000$ (b) magnification of the scratch area after 21 days of the $\mathrm{SO}_{2}$ test pointing out the main EDS spectra recorded in this sample (quantitative results in Table 4)

Fig. 5. BSE micrograph at $\times 500$ (a) and $\times 2000$ (b) magnification of the scratch after 21 days of the $\mathrm{H}_{2} \mathrm{~S}$ test pointing out the main EDS spectra recorded in this sample (quantitative results in Table 5).

Fig. 6. BSE micrographs of the scratch after 21 days of $\mathrm{NO}_{2}$ test. View of the whole scratch at $95 x$ (a) and the reflective layer at x5000 (b) and x10000 (c to e). The location of the EDS spectra listed in Table 6 is pointed out.

Fig. 7. BSE micrographs of the scratch area after 21 days of the humidity test at $40{ }^{\circ} \mathrm{C}$ (K_0_40 sample). View of the whole scratch at $\times 200$ (a), corrosion deposits near the reflective layer at $\times 2.0 \mathrm{k}$ (b), highly corroded (c) and initially protected (non-corroded) (d) reflective layer at $\times 8.0 \mathrm{k}$ magnification. The location of the main EDS spectra listed in Table 7 are pointed out.

Fig. 8. BSE micrographs of the scratch area after 20 days of the Kesternich test at $667 \mathrm{ppm} \mathrm{SO}_{2}$, $40{ }^{\circ} \mathrm{C}$ and $100 \%$ RH (K_0.2_40 sample). View of the whole scratch at $\times 200$ showing the original edge of paint layers on the top and a delaminated area on the bottom of the image (a). Zoom at $\times 1000$ of the paints original edge (b) and the delaminated edge (c). View at $\times 500$ of the paint and reflective layers at the end of the delaminated area, positioned at about $2 \mathrm{~mm}$ from the scratch edge initially exposed to the corrosive atmosphere (d). The location of the main EDS spectra listed in Table 8 are pointed out. 
Fig. 9. BSE micrograph of the reflective layer at the end of the delaminated area (near spectrum \#27 position) (a). EDS microanalysis results: Spectrum \#28 and 29 and $\mathrm{Cu} K \alpha 1$ mapping (b).

Fig. 10. BSE micrographs recorded on a delaminated area near the scratch (a) and on the inner part of the delaminated paint flake (b) in the K_2_40 sample. Some rests of the inner paint layer, which is $\mathrm{S}$ and $\mathrm{Zn}$-rich (lighter color), are observed on the glass substrate and on the delaminated part of the coating. The location of the main EDS spectra listed in Table 10 are pointed out.

Fig. 11. SE micrograph (topographic) of the delaminated scratch edge in the K_0.2_40 sample recorded at $\times 1.0 \mathrm{k}$ and $6 \mathrm{kV}$. Fig. 8.c showed the BSE micrograph (compositional) of the same area at the same magnification and $16 \mathrm{kV}$.

Fig. 12. BSE micrograph of the intentionally delaminated area near the scratch of the K_1_50 sample after 10 aging cycles.

Fig. 13. BSE micrograph of the delaminated area near the scratch of the K_1_50_10cy sample. The red circle shows the area selected for the Site 1 (a) and Site 2 (b) cross-section analyses.

Fig. 14. BSE micrographs recorded during the cross-section preparation of Site 1 (a) and Site 2 (b) with the FIB workstation. From top to bottom, Site 1 images (a) show the site selection, the electron and ion-deposited platinum protective strip and the sample cross-section after milling with Ga-sputtering. At Site 2 (b) the displayed images were recorded after the electrondeposited Pt, the ion-deposited Pt and the Ga sputtering.

Fig. 15. BSE micrographs at different magnifications of the Site 1 FIB cross-section in the silvered-glass reflector of K_1_50 test after 10 cycles. Three regions are distinguished in the whole cross-section: The reflective layer under the paint coatings (a), only the silver layer on the glass substrate (b) and the $\mathrm{Cu}$ island on the Ag thin-layer (c).

Fig. 16. BSE micrographs at different magnifications of the Site 2 FIB cross-section in the silvered-glass reflector of $K_{-} 1 \_50$ test after 10 cycles. The Ag layer is corroded and separated from the glass substrate inside the wrinkle. 